- FINANSE I PRAWO FINANSOWE.

- Journal of Finance and Financial Law

Grudzień/December 2020 • vol. 4(28): 129-147

http://dx.doi.org/10.18778/2391-6478.4.28.08

\title{
OCENA ZMIAN DOCHODÓW ORAZ WYDATKÓW POLSKICH GOSPODARSTW DOMOWYCH W LATACH 2008-2018
}

\author{
Paweł Socha \\ Uniwersytet Marii Curie-Skłodowskiej w Lublinie \\ Paulina Szynkaruk \\ Uniwersytet Marii Curie-Skłodowskiej w Lublinie
}

\begin{abstract}
Streszczenie
W ostatnich latach sytuacja gospodarcza w Polsce podlegała dynamicznym zmianom. Zmiany te oddziaływały na poziom życia Polaków poprzez wpływ na ich sytuację finansową. Artykuł przedstawia oraz analizuje charakterystykę zmian w strukturze budżetów gospodarstw domowych w latach 2008-2018. Omówione zostały zagadnienia, takie jak poziom dochodów i wydatków, struktura wydatków, tendencja oraz dynamika zmian z uwzględnieniem czynników demograficznych i ekonomicznych. Oprócz przeanalizowania danych dotyczących struktury budżetów gospodarstw domowych, zidentyfikowane zostały również przyczyny odpowiadające za takie, a nie inne kierunki zmian.
\end{abstract}

Słowa kluczowe: struktura budżetu, gospodarstwa domowe, zmiany, otoczenie ekonomiczne, otoczenie polityczne, otoczenie społeczne, otoczenie technologiczne.

JEL Class: R21. 


\section{WSTĘP}

Przedmiotem przedstawionej problematyki jest budżet gospodarstw domowych i zmiany, jakie dokonały się w latach 2008-2018. Celem artykułu jest zestawienie danych dotyczących struktury budżetów polskich gospodarstw domowych w latach 2008-2018 i wykazanie tendencji w nich zachodzących oraz ich przyczyn. Pojęcie budżetu gospodarstw domowych definiuje Główny Urząd Statystyczny, według którego jest to systematyczne zestawienie (według klasyfikacji) przychodów i rozchodów (pieniężnych i niepieniężnych) gospodarstwa domowego za dany okres [GUS 2009: 14]. Za przychody netto uważa się wszystkie wartości wpływające do gospodarstwa domowego, bez zaliczek na podatek dochodowy od osób fizycznych płaconych przez płatnika w imieniu podatnika, jak również bez składek na ubezpieczenia społeczne i zdrowotne. Na przychody netto składają się dochód rozporządzalny i pozycje oszczędnościowe po stronie przychodowej [GUS 2009: 14]. Zaś rozchody netto określa się jako wszystkie wartości wypływające z gospodarstwa na zewnątrz, bez zaliczek na podatek dochodowy od osób fizycznych płaconych przez płatnika w imieniu podatnika, jak również bez składek na ubezpieczenia społeczne i zdrowotne. Na rozchody netto składają się wydatki i pozycje oszczędnościowe po stronie rozchodowej [GUS 2009: 14]. W terminologii pojawia się także pojęcie dochodu rozporządzalnego związanego $\mathrm{z}$ tematyką prezentowanych pojęć. Jest ono przedstawione jako suma bieżących dochodów gospodarstwa domowego z poszczególnych źródeł pomniejszona o zaliczki na podatek dochodowy od osób fizycznych płacone przez płatnika w imieniu podatnika (od dochodów z pracy najemnej oraz od niektórych świadczeń z ubezpieczenia społecznego i świadczeń pomocy społecznej), o podatki od dochodów i własności płacone przez osoby pracujące na własny rachunek, w tym przedstawicieli wolnych zawodów i osób użytkujących gospodarstwo indywidualne w rolnictwie oraz o składki na ubezpieczenia społeczne i zdrowotne. W skład dochodu rozporządzalnego wchodzą dochody pieniężne i niepieniężne, w tym spożycie naturalne (towary i usługi konsumpcyjne pobrane na potrzeby gospodarstwa domowego z gospodarstwa indywidualnego w rolnictwie bądź działalności gospodarczej na własny rachunek) oraz towary i usługi otrzymane nieodpłatnie [GUS 2009: 14]. Zaprezentowana wyżej terminologia ma na celu zobrazować i objaśnić pojęcia związane z głównym tematem pracy. Źródłem analizowanych danych są wyniki badań statystycznych prezentowanych w Głównym Urzędzie Statystycznym oraz literaturze naukowej. 


\section{STRUKTURA DEMOGRAFICZNA W POLSCE}

Prezentując dane demograficzne występujące w Polsce, należy zacząć od przytoczenia definicji demografii. Według Encyklopedii PWN, jest to dyscyplina naukowa, która podejmuje badania zjawisk ludnościowych, zmierzające do wykrycia prawidłowości, którym te zjawiska podlegają [Okólski 2020: 1]. Podobnie obrazuje to pojęcie Jerzy Z. Holzer, według którego jest to nauka zajmująca się badaniem prawidłowości zjawisk ludnościowych w konkretnych warunkach społecznych i gospodarczych danego terytorium, która ,zajmuje się statystyczno-analitycznym opisem stanu i struktury ludności oraz badaniem i oceną zmian wynikających z dotychczasowego i przewidywanego ruchu naturalnego i wędrówkowego" [Holzer 2003: 13]. Zagłębiając się w terminologię powyższych definicji, możemy zauważyć, iż w obu przytoczonych pojęciach, podmiotem badanym jest populacja, definiowana jako grupa osobników jednego gatunku zamieszkujących dany obszar [Weiner 1999: 40]. Struktura zaś formułowana jest jako rozmieszczenie elementów składowych danego układu i zespół relacji (wzajemnych powiązań) między tymi elementami, charakterystyczny dla tego układu [WNT 1984]. Opierając się na powyższych definicjach, pojęcie struktury demograficznej oznacza układ wzajemnie powiązanych elementów zajmujący się badaniem zjawisk ludnościowych, opisem stanu i struktury ludności oraz badaniem i oceną zmian wynikających z tych zjawisk.

Struktura demograficzna w Polsce w latach 2008-2018 określana jest jako trudna. Według Głównego Urzędu Statystycznego w najbliższej perspektywie nie można spodziewać się znaczących zmian gwarantujących stabilny rozwój demograficzny. Niski nadal poziom dzietności będzie miał negatywny wpływ także na przyszłą liczbę urodzeń, ze względu na zdecydowanie mniejszą w przyszłości liczbę kobiet w wieku rozrodczym. Zjawisko to dodatkowo jest potęgowane wysoką skalą emigracji Polaków za granicę (szczególnie dotyczy to emigracji czasowej ludzi młodych). Niski poziom dzietności i urodzeń przy jednoczesnym korzystnym zjawisku, jakim jest stosunkowo długie trwania życia, będzie powodować zmniejszanie podaży pracy oraz coraz szybsze starzenie się społeczeństwa poprzez przede wszystkim wzrost liczby i udziału w ogólnej populacji ludności w najstarszych rocznikach wieku [GUS 2019: 17]. Sytuacje obrazującą to zjawisko można zaobserwować w poniżej zaprezentowanej tabeli 1. 
Tabela 1. Ludność według grup wieku w Polsce w wybranych latach

\begin{tabular}{|l|c|c|c|c|c|c|c|c|c|c|c|c|}
\hline \multirow{2}{*}{ Grupy wieku } & \multicolumn{8}{|c|}{ Ludność (stan w dniu 31.12) w latach: } \\
\cline { 2 - 13 } & 1990 & 2000 & 2010 & 2017 & 2018 & 1990 & 2000 & 2010 & 2017 & 2018 \\
\cline { 2 - 12 } & \multicolumn{8}{|c|}{ w tysiącach } \\
\hline Ludność ogółem & 38073 & 38254 & 38530 & 38434 & 38411 & 100,0 & 100,0 & 100,0 & 100,0 & 100,0 \\
\hline Mediana wieku & 32,3 & 35,4 & 38,0 & 40,6 & 40,9 & x & x & x & x & x \\
\hline \multicolumn{8}{|c|}{ Biologiczne grupy wieku } \\
\hline 0-14 lat & 9495 & 7294 & 5856 & 5834 & 5865 & 24,9 & 19,1 & 15,2 & 15,2 & 15,3 \\
\hline 15-64 lata & 24705 & 26234 & 27484 & 26089 & 25814 & 64,9 & 68,5 & 71,3 & 67,9 & 67,2 \\
\hline 65 i więcej lat & 3873 & 4726 & 5190 & 6520 & 6732 & 10,2 & 12,4 & 13,5 & 17,0 & 17,5 \\
\hline & \multicolumn{7}{|c|}{ Ekonomiczne grupy wieku } \\
\hline $\begin{array}{l}\text { Przedprodukcyjnym } \\
\text { (0-17 lat) }\end{array}$ & 11286 & 9333 & 7243 & 6921 & 6936 & 29,6 & 24,4 & 18,8 & 18,0 & 18,1 \\
\hline $\begin{array}{l}\text { Produkcyjnym } \\
\text { (18-59/64) }\end{array}$ & 21898 & 23261 & 24831 & 23518 & 23270 & 57,5 & 60,8 & 64,4 & 61,2 & 60,6 \\
\hline Mobilnym (18-44) & 15447 & 15218 & 15424 & 14860 & 14676 & 40,6 & 39,8 & 40,0 & 38,7 & 38,2 \\
\hline Niemobilnym (44-59/64) & 6452 & 8043 & 9407 & 8658 & 8594 & 16,9 & 21,0 & 24,4 & 22,5 & 22,4 \\
\hline $\begin{array}{l}\text { Poprodukcujnym } \\
\text { (60/65 lat+) }\end{array}$ & 4889 & 5660 & 6456 & 7995 & 8206 & 12,9 & 14,8 & 16,8 & 20,8 & 21,4 \\
\hline
\end{tabular}

Źródło: GUS, 2019, Sytuacja demograficzna ...: 30.

Na podstawie danych Głównego Urzędu Statystycznego możemy zauważyć, iż w latach 2000-2009 wśród ludności w wieku produkcyjnym obserwowano duże zmiany wynikające $\mathrm{z}$ wchodzenia $\mathrm{w}$ ten wiek osób urodzonych $\mathrm{w}$ okresie wyżu demograficznego z pierwszej połowy lat 80. ub. wieku. Intensywnie rosła zarówno liczebność, jak i udział tej grupy w ogólnej populacji. Od 2010 r. odsetek grupy osób w wieku produkcyjnym obniża się i w 2018 r. osiągnął poziom $60,6 \%$, tj. 23,3 mln - czyli o 248 tys. mniej niż rok wcześniej. Wynika to z procesu przesuwania do grupy wieku poprodukcyjnego licznych roczników osób urodzonych w latach 50. XX w. oraz z coraz mniejszej liczebności 18-latków, zasilających wiek produkcyjny. Zahamowaniu uległ proces starzenia się zasobów pracy, tj. maleją zarówno liczba, jak i udział ludności w wieku produkcyjnym niemobilnym, której udział w 2018 r. wyniósł 22,4\%. Zmniejszyła się także liczba i odsetek ludności w wieku produkcyjnym mobilnym, który w latach 1990-2014 oscylował wokół 40\% - w końcu 2018 r. wyniósł 38,2\% [GUS 2019: 30]. Ludność w wieku przedprodukcyjnym w 2018 roku wyniosła 18,1\%, co w porównaniu z rokiem 2010 oznacza spadek liczebności tej grupy, zaś wzrosła w porównaniu do poprzedniego roku. Liczebność grupy poprodukcyjnej w 2018 roku wyniosła 21,4\% ludności ogółem. Udział wydatków w dochodzie rozporządzalnym w poszczególnych grupach społeczno-ekonomicznych doskonale obrazuje zaprezentowany poniżej wykres 1. 


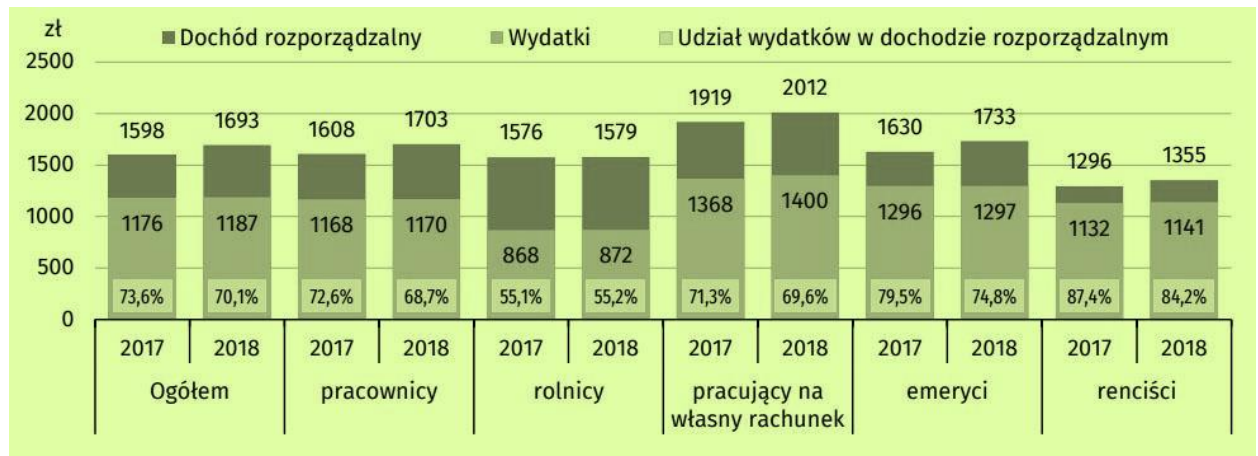

Wykres 1 . Przeciętny miesięczny dochód rozporządzalny i wydatki na 1 osobę w gospodarstwach domowych oraz udział przeciętnych miesięcznych wydatków w dochodzie rozporządzalnym według grup społeczno-ekonomicznych w latach 2017-2018

Źródło: GUS, 2019, Budżety gospodarstw...: 23.

Mediana przeciętnego miesięcznego dochodu rozporządzalnego na 1 osobę w zaokrągleniu do 1 zł w 2018 r. wynosiła 1477 zł, a przeciętnych miesięcznych wydatków 976 zł. Mediana dochodu rozporządzalnego na 1 osobę stanowiła $87,2 \%$ wartości przeciętnego miesięcznego dochodu rozporządzalnego, zaś mediana wydatków $82,3 \%$ wartości przeciętnych miesięcznych wydatków na 1 osobę (w 2017 r. odpowiednio 86,7\% i 83,3\%). Iloraz mediany do wartości przeciętnej miesięcznej na 1 osobę w przypadku dochodu rozporządzalnego był najwyższy w grupie gospodarstw domowych emerytów, a najniższy w gospodarstwach rolników. W przypadku zaś wydatków, był najwyższy w gospodarstwach domowych emerytów, a najniższy u pracujących na własny rachunek [GUS 2019: 23].

\section{WPŁYW OTOCZENIA POLITYCZNO-PRAWNEGO, EKONOMICZNEGO, SPOŁECZNEGO I TECHNOLOGICZNEGO NA STRUKTURĘ BUDŻETU GOSPODARSTW DOMOWYCH W POLSCE W LATACH 2008-2018}

Kształtowanie się zmian w strukturze budżetów polskich gospodarstw domowych zależy od różnych aspektów otoczenia. W kontekście organizacji, pojęcie otoczenia autorzy Koźmiński i Piotrowski przedstawiają między innymi jako otoczenie, które wpływa na warunki organizacji i jej funkcjonowania, określa reguły gry, a także możliwości rozwoju, kreując szanse, ale również bariery i zagrożenia [Koźmiński i Piotrowski 2002: 30]. Podobnie wyglada sytuacja dotycząca otoczenia, które wpływa na zmiany w strukturze. Każda modyfikacja ma znaczący 
wpływ na to, jak kształtuje się sytuacja budżetów domowych w Polsce. Prezentuje, jak zmieniały się poszczególne czynniki budżetu, jakie zmiany dokonały się w dochodach Polaków, a jaką rolę pełniły w tym wydatki.

\subsection{OTOCZENIE POLITYCZNO-PRAWNE}

Duży wpływ na strukturę budżetu w głównej mierze ma otoczenie polityczno-prawne. Stanowi ono zbiór regulacji działalności gospodarczej oraz relacje między państwem a gospodarką. Otoczenie polityczne obejmuje m.in. system polityczny, sposoby sprawowania władzy, stopień ingerencji polityki w inne sfery życia społecznego, tj. oświatę, kulturę, gospodarkę itd. Otoczenie prawne bazuje natomiast na porządku prawnym i stopniu szczegółowości przyjętych norm [Marek i Białasiewicz 2008: 102]. Na przestrzeni lat 2008-2018 w Polsce dominowały dwie partie rządzące: Prawo i Sprawiedliwość oraz Platforma Obywatelska. Obie partie wprowadzały w życie różnorodne zmiany dotyczące podatków, świadczeń socjalnych czy zmian prawa, które w znaczny sposób przyczyniły się do zmian w strukturze budżetów polskich gospodarstw domowych. Do kluczowych zmian w tych latach możemy zaliczyć wprowadzenie świadczenia wychowawczego Rodzina 500+. Wprowadzony w 2016 roku program, na podstawie Głównego Urzędu Statystycznego, stanowił przeciętnie w gospodarstwach domowych otrzymujących to świadczenie $16,8 \%$ dochodów rozporządzalnych na 1 osobę [GUS 2017: 42]. Zaś przeciętne miesięczne dochody na 1 osobę w gospodarstwach domowych pobierających świadczenie wychowawcze Rodzina 500+ w 2018 r. stanowiły 78,9\% przeciętnych dochodów w gospodarstwach domowych ogółem [GUS 2019: 38]. Możemy zauważyć znaczny przyrost udziału w dochodach gospodarstw domowych, jaki spowodowało wprowadzenie tego programu.

Innym czynnikiem mającym wpływ na zmiany struktur budżetów polskich gospodarstw domowych są wszelkie zmiany w prawie. W latach 2008-2018 mogliśmy zaobserwować zmiany dotyczące prawa dla przedsiębiorców, między innymi zmieniły się wytyczne zatrudniania młodocianych czy zmiany dotyczące świadczeń społecznych pracowników. Nastąpiły również zmiany prawa podatkowego, między innymi VAT czy akcyza. Na przestrzeni tych lat, prawo charakteryzowało się dużymi zmianami, poszczególne zmiany w kluczowy sposób wpływały na zmiany dotyczące struktury budżetu polskich gospodarstw domowych.

\subsection{OTOCZENIE EKONOMICZNE}

Determinantem wpływającym na strukturę gospodarstw domowych jest otoczenie ekonomiczne. Otoczenie ekonomiczne jest określane jako zależne od ogólnej sytuacji i kondycji systemu gospodarczego, w którym działa przedsiębiorstwo. 
Miernikami pozwalającymi mierzyć stan tego wymiaru są m.in. produkt krajowy brutto, inflacja, bezrobocie, stopy procentowe, poziom i wahania kursów kredytowych [Marek i Białasiewicz 2008: 102]. W 2009 roku Polska weszła w okres spowolnienia gospodarczego spowodowanego wcześniejszym globalnym kryzysem gospodarczym. Spowolnienie gospodarcze miało znaczący wpływ na zmiany zachowań gospodarstw domowych. Osłabienie koniunktury gospodarczej powoduje zmiany w poziomie zatrudnienia i płac, oznaczając dla gospodarstw domowych spadek dochodów, a w skrajnych wypadkach także całkowitą utratę dotychczasowych źródeł utrzymania. Wzrost zagrożenia utratą pracy lub obniżenie wysokości dochodów wpływa destabilizująco na poczucie bezpieczeństwa ekonomicznego gospodarstw domowych, co z kolei znajduje bezpośrednie przełożenie w zachowaniach nabywczych gospodarstw domowych na rynku dóbr i usług [Zalega 2012: 91-109]. Kryzys gospodarczy wpłynął na zjawisko bezrobocia. Na obszarach stagnacji, relatywnie mniej było gospodarstw domowych, w których ktoś znalazł pracę w latach 2008-2013, co skutkowało wyższym udziałem gospodarstw domowych, w których co najmniej dwie osoby były bez pracy. Na obszarach wzrostu częściej znajdowano pracę i rzadziej ją tracono [Dominiak i Konecka-Szydłowska 2014: 108, co z kolei spowodowało poprawę sytuacji materialnej gospodarstw domowych. Kryzys gospodarczy odbił się też na strukturze wydatków gospodarstw domowych. Odnotowano wzrost udziału wydatków na produkty podstawowe (żywność i napoje bezalkoholowe) oraz transport indywidualny, przy jednoczesnym spadku udziału wydatków na dobra i usługi bardziej luksusowe (np. hotele i restauracje oraz rekreację, wyposażenie mieszkania czy wyjazdy wakacyjne). Kryzys gospodarczy spowodował wzrost poziomu zadłużenia relatywnie większej liczby gospodarstw domowych, a także więcej gospodarstw zostało zmuszonych do zaciągnięcia kredytu ze względu na pogorszenie sytuacji materialnej. W 2008 roku o kredyt wnioskowało 22 miliony osób; to o 4 miliony więcej niż w poprzenim roku [KNF 2018]. Kryzys gospodarczy wpłynął także na decyzje dotyczące zachowań prorodzinnych. $Z$ przyczyn finansowych odkładano $\mathrm{w}$ czasie posiadanie pierwszego i kolejnych dzieci, a nawet rezygnowano $\mathrm{z}$ ich posiadania [KNF 2018].

Kryzys gospodarczy to tylko jeden z czynników otoczenia ekonomicznego wpływający na zmiany struktury budżetów gospodarstw domowych. Kolejnym czynnikiem jest wzrost wynagrodzeń. Przeciętne wynagrodzenie brutto w gospodarce narodowej w 2008 roku wynosiło 2943,88 zl, w 2015 r. wynosiło już 3899,78 zł, w 2018 r. sięgało 4585,03 zł [GUS 2020]. Oprócz wzrostu wynagrodzeń możemy także zaobserwować wzrost płac minimalnych. W 2018 r. płaca minimalna brutto została ustalona na $2100 \mathrm{zł}$, w porównaniu do $2017 \mathrm{r}$. wzrosła o 5\% [GUS 2020]. Wzrost płac minimalnej, a także wynagrodzeń, poprawiało sytuację materialną polskich gospodarstw domowych. W minionych latach nastąpiły również zmiany dotyczące mierników ekonomicznych. Na koniec roku 2008 
stopa bezrobocia wynosiła 9,5\%, w ciągu kolejnych 5 lat wzrosła aż do 13,4\%, po czym w 2018 roku kształtowała się na poziomie 5,8\% [GUS 2020]. Poziom inflacji w 2008 roku kreował się na poziomie 4,2\%, w 2018 wynosił 1,6\% [GUS 2020]. Sposób, w jaki kształtowały się powyższe mierniki ekonomiczne mają kluczowe znaczenie w budowaniu ogólnej kondycji systemu gospodarczego, co z kolei wpływa na modelowanie się struktury budżetów polskich gospodarstw domowych.

\subsection{OTOCZENIE SPOŁECZNE}

Kolejnym czynnikiem wpływającym na strukturę budżetów polskich gospodarstw domowych jest otoczenie społeczne, przedstawiane jest jako zbiór nawyków, zwyczajów, norm, wartości i cech demograficznych społeczeństwa, które oddziałują na organizację [Marek i Białasiewicz 2008: 103]. W latach 2008-2018 możemy zaobserwować zmiany stylu życia Polaków. Styl życia to także styl konsumpcji, który stanowi często wyznacznik pozycji społecznej oraz osobowości nabywcy. Konsumpcja wyraża przyjęty, świadomie lub nieświadomie, styl życia. Wraz z nią następuje aranżacja przestrzeni, formy spędzania wolnego czasu, a przede wszystkim uczestnictwo w różnych wymiarach kultury - koncertach, wystawach, festynach itp. [Pizło i Mazurkiewicz-Pizło 2017: 107]. Zmiany w zakresie konsumpcji wiążą się ze zmianą wydatków w strukturze budżetów gospodarstw domowych.

Kolejnym czynnikiem charakteryzującym otoczenie społeczne jest urbanizacja. Jest to proces koncentracji ludności w punktach przestrzeni geograficznej, głównie na obszarach miejskich, określający także wzrost liczby ludności miejskiej i jej udziału w liczbie ludności danego obszaru, dzięki czynnikom społeczno-kulturowym, demograficznym i ekonomicznym [Węcławowicz 2003: 102]. Urbanizacja oznacza także przestrzenny rozwój miast oraz zmianę stylu życia na miejski [Węgleński 2002: 276]. Zmiana stylu życia na miejski jest związana również z większymi wydatkami w budżetach gospodarstw domowych.

\subsection{OTOCZENIE TECHNOLOGICZNE}

Nie mniej ważnym niż pozostałe czynniki wpływające na strukturę budżetu poskich gospodarstw domowych jest otoczenie technologiczne. Otoczenie technologiczne tworzą dostępne metody i technologie, dzięki którym zasoby mogą być przekształcane w produkty i usługi. Zawiera on zarówno fizyczne wytwory techniki, tj. maszyny, urządzenia, infrastruktura, a także zasoby wiedzy oraz know how. Otoczenie to w dużym stopniu uzależnione jest od tempa rozwoju technicznego i dynamiki zmian poszczególnych sektorów [Marek i Białasiewicz 2008: 103]. Dostęp do nowych technologii zmienia rzeczywistość, wpływa na poziom 
i jakość życia gospodarstw domowych, pozwala zaoszczędzić czas, daje możliwość korzystania z dóbr, które bez nich niejednokrotnie są nieosiągalne, a co za tym idzie wpływa na rozwój gospodarczy [Pekasiewicz i Szczukocka 2017: 247]. Usługi oparte na nowych technologiach charakteryzują się dużymi zmianami. Jest to widoczne w liczbie komputerów, dostępie do Internetu oraz pojawieniu się tabletów i smartfonów. Na rynku obserwuje się spowolnienie upowszechnienia technologii ICT, typu komputer czy Internet stacjonarny, na rzecz nowszych, np. Internet mobilny oferowany przez telefonie komórkowe użytkownikom smartfonów i tabletów. Ograniczenia dostępności do nowych technologii w gospodarstwach domowych związane są m.in. z miejscem zamieszkania, liczbą dzieci w rodzinie i statusem finansowym [Pekasiewicz i Szczukocka 2017: 257]. Korzystanie z nowych technologii ma bezpośrednie znaczenie dla firm, organizacji i administracji publicznej, są one bowiem środkiem do podnoszenia efektywności i wydajności pracy, a coraz częściej także narzędziem dostępu do usług, w tym usług publicznych świadczonych drogą elektroniczną [Pekasiewicz i Szczukocka 2017: 258], co z kolei ma kluczowe znaczenie dla gospodarstw domowych. W obecnych czasach przedsiębiorcy, w głównej mierze, aby ponosić niższe koszty, stawiają na automatyzację pracy, czyli znaczne ograniczenie lub zastąpienie (proces zastępowania) ludzkiej pracy fizycznej i umysłowej przez pracę maszyn działających na zasadzie samoregulacji i wykonujących określone czynności bez udziału człowieka [Gupta 2007: 1], przez co przyczynia się do zwiększenia wydajności pracy, ale także zmniejszenia zatrudnienia. Może to bezpośrednio doprowadzić do utraty zatrudnienia, co z kolei będzie miało wpływ na osiągane dochody przez gospodarstwa domowe.

\section{ZMIANY W STRUKTURZE BUDŻETÓW POLSKICH GOSPODARSTW DOMOWYCH}

Niniejszy rozdział zawiera zestawienie danych z Głównego Urzędu Statystycznego dotyczących różnych aspektów związanych z budżetami gospodarstw domowych w Polsce. Dane zostały zaprezentowane w ujęciu wieloletnim, a następnie przeprowadzono analizę trendu i dynamiki zmian oraz ich potencjalnych przyczyn i skutków ekonomicznych dla gospodarki państwa.

Główny Urząd Statystyczny od 1957 roku prowadzi coroczne badania dotyczące budżetów gospodarstw domowych [GUS 2015]. Badania obejmują szeroki zakres zagadnień związanych z przychodami i wydatkami Polek i Polaków. Przedstawione są w nich między innymi dane o przeciętnych dochodach gospodarstw domowych, w podziale na miejsce zamieszkania (podział na województwa, a także z podziałem na ośrodki zamieszkania np. wsie, małe miasta, duże miasta), strukturę dochodów (rozróżnienie kategorii źródeł dochodów), oraz o wydatkach (tu również rozróżniane jest wiele kategorii np. struktura 
wydatków). Badania Głównego Urzędu Statystycznego stanowią kompleksową i wyjątkowo rzetelne źródło, które zostało poddane wieloletniemu zestawieniu oraz analizie w niniejszym artykule.

W latach 2008-2018 przeciętne dochody polskich gospodarstw domowych cechowały cię corocznymi wzrostami. Tendencja ta była stała - w żadnym z badanych okresów czasowych poziom przeciętnych dochodów gospodarstw domowych nie był niższy niż w roku go poprzedzającym. Na systematyczny wzrost dochodów Polaków wpływało wiele różnorodnych czynników składających się na sprzyjającą sytuację ekonomiczną i rozwój gospodarki kraju. W badanym okresie Polska rokrocznie odnotowywała dodatni wzrost gospodarczy. Wskaźniki wzrostu gospodarczego z poszczególnych lat nie wskazywały na trend wzrostowy lub spadkowy. Jedynie w latach badania 2016-2017 widać wzrost dynamiki.

\begin{tabular}{|c|c|c|c|c|c|c|c|c|c|c|c|}
\hline Wyszczególnienie & 2008 & 2009 & 2010 & 2011 & 2012 & 2013 & 2014 & 2015 & 2016 & 2017 & 2018 \\
\hline $\begin{array}{c}\text { Wskaźnik wzrostu } \\
\text { gospodarczego } \\
\text { w Polsce [\%] }\end{array}$ & 5 & 1,8 & 3,8 & 4,3 & 1,9 & 1,6 & 3,4 & 3,6 & 3 & 4,6 & 5,1 \\
\hline
\end{tabular}

Rysunek 3. Wzrost gospodarczy w Polsce w latach 2008-2018

Źródło: opracowanie własne na podstawie danych GUS - roczne wskaźniki makroekonomiczne 2018-2018.

Istotny udział we wzroście dochodów w ostatnich trzech latach miał z pewnością wprowadzony 1 kwietnia 2016 roku rządowy program wspierania demografii Rodzina 500+ [Ministerstwo Rodziny i Polityki Społecznej 2020]. Założeniem programu była comiesięczna wypłata kwoty 500 zł przypisanej do dzieci, które nie ukończyły 18 roku życia (początkowo świadczenia wypłacane były tylko na drugie dziecko i następne w rodzinie; aby otrzymywać świadczenie na pierwsze dziecko należało spełniać kryterium niskich dochodów; od 1 lipca 2019 roku świadczenia przyznawane było na każde dziecko). Efektami programu był nominalny wzrost dochodów rodzin posiadających dzieci oraz stymulacja wzrostu gospodarczego poprzez konsumpcję. Na poziom dochodów polskich gospodarstw domowych miały też wpływ wzrosty płac oraz podwyższenie płacy minimalnej.

Poziom przeciętnych dochodów polskich gospodarstw domowych systematycznie rósł $\mathrm{w}$ okresie badania. Wartości wskaźnika przeciętnego dochodu na jedną osobę w gospodarstwie domowym wzrastały co roku - od 1046 zł w 2008 roku do $1693 \mathrm{zł} \mathrm{w} 2018$ roku.

W latach 2008-2018 poziom przeciętnych wydatków na jedną osobę systematycznie rósł. Trend wzrostowy nie był jednak równie dynamiczny, jak 
w przypadku dochodów (pojawily się nadwyżki finansowe przeznaczone na oszczędno-ści lub inwestycje). W okresie objętym badaniem, poziom przeciętnych wydatków gospodarstw domowych wzrastał od 911 zł w 2008 r. do 1187 zł w 2018 r. Dynamika wzrostu tych wartości nie odznaczała się gwałtownymi zmianami.

Jako że dochody rosły w tempie szybszym niż wydatki, wśród polskich gospodarstw domowych (w ujęciu statystycznym) pojawiły się nadwyżki finansowe. Dochód rozporządzalny rósł w tempie dużo szybszym niż dochody czy wydatki, jednak dynamika jego zmian zbliżona była do zmian poziomów dochodów. W analizowanym okresie kategoria ta powiększyła się ponad trzykrotnie - od $135 \mathrm{zł}$ dochodów rozporządzalnego w 2008 roku do 506 zł w roku 2018. Wzrost dochodu rozporządzalnego jest elementem niezwykle istotnym w procesie bogacenia się społeczeństwa. Dzięki wolnym środkom finansowym jednostki mogą poprawiać swój standard życia poprzez wzrost konsumpcji lub budować zabezpieczenie majątkowe poprzez oszczędności.

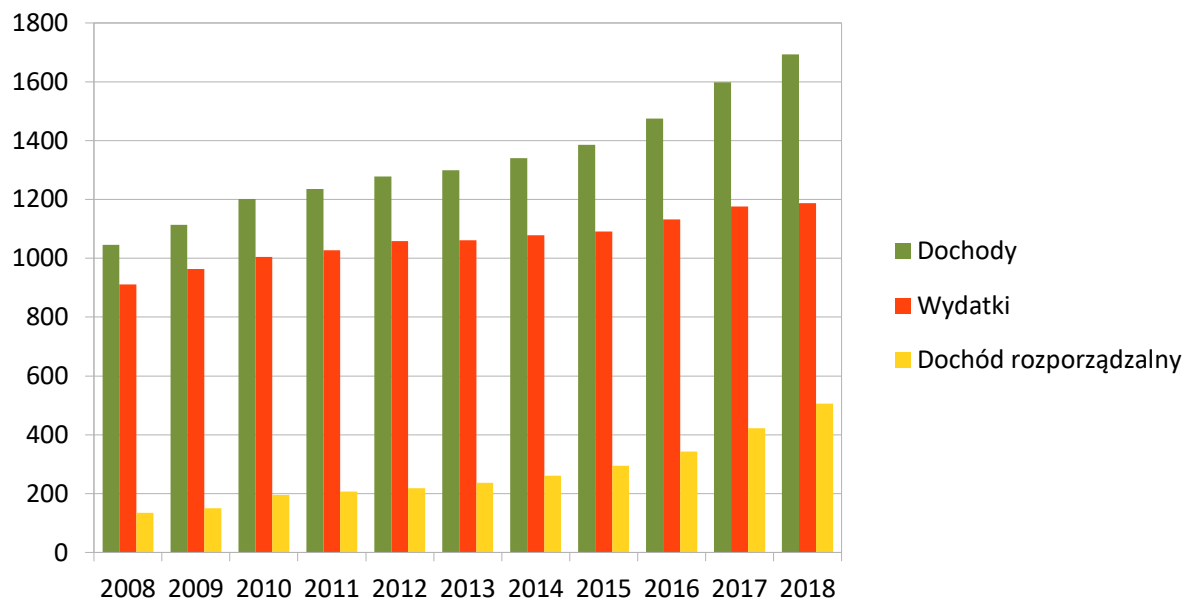

Rysunek 4. Poziom przeciętnych miesięcznych dochodów, wydatków i dochodu rozporządzalnego na jedną osobę w latach 2008-2018

Źródło: opracowanie własne na podstawie danych GUS, 2008-2018, Budżety gospodartw...

Struktura przeciętnego miesięcznego dochodu rozporządzalnego na jedną osobę $\mathrm{w}$ gospodarstwie domowym cechowała się niewielką dynamiką zmian w okresie badania (rzędu od 2,8\% do 6,5\%). Największymi kategoriami dochodów były: dochody z pracy najemnej oraz dochody ze świadczeń z ubezpieczeń 
społecznych (głównie emerytury). Różnice między udziałem danej kategorii dochodu w okresie badania wynosiły maksymalnie kilka punktów procentowych. Zauważalne tendencje zmian struktury przeciętnych dochodów w latach 20082018:

- słaba tendencja spadkowa dochodów z pracy najemnej,

- spadek udziału dochodów z rent w przeciętnej strukturze dochodów,

- silna tendencja wzrostowa dochodów z pozostałych świadczeń społecznych (świadczenie wychowawcze, zasiłek dla bezrobotnych, świadczenie Rodzina 500+).

Wzrost udziału danej kategorii mógł mieć dwie przyczyny:

- dynamiczny wzrost dochodów danej kategorii w stosunku do pozostałych źródeł dochodów,

- pozostawanie danej kategorii na tym samym poziomie przy jednoczesnym obniżaniu się wartości pozostałych kategorii.

Biorąc pod uwagę istotne wzrosty przeciętnego poziomu dochodów gospodarstw domowych w okresie badania, wzrosty wyżej wymienionych kategorii spowodowane były najprawdopodobniej ich ponadprzeciętnym wzrostem w stosunku do innych kategorii.

\begin{tabular}{|l|c|c|c|c|c|c|c|c|c|c|c|}
\hline Kategoria dochodów & $\mathbf{2 0 0 8}$ & $\mathbf{2 0 0 9}$ & $\mathbf{2 0 1 0}$ & $\mathbf{2 0 1 1}$ & $\mathbf{2 0 1 2}$ & $\mathbf{2 0 1 3}$ & $\mathbf{2 0 1 4}$ & $\mathbf{2 0 1 5}$ & $\mathbf{2 0 1 6}$ & $\mathbf{2 0 1 7}$ & $\mathbf{2 0 1 8}$ \\
\hline Dochody z pracy najemnej & 55,7 & 55,4 & 55,5 & 56,4 & 55,6 & 55,0 & 55,9 & 56,7 & 54,6 & 52,1 & 52,6 \\
\hline $\begin{array}{l}\text { Dochody z pracy na własny } \\
\text { rachunek }\end{array}$ & 9,1 & 9,5 & 9,5 & 9,2 & 8,8 & 8,9 & 8,9 & 8,9 & 8,7 & 8,4 & 8,7 \\
\hline $\begin{array}{l}\text { Dochody z gospodarstwa } \\
\text { rolnego }\end{array}$ & 4,3 & 4,0 & 4,4 & 3,8 & 4,3 & 4,6 & 3,5 & 3,3 & 3,4 & 4,2 & 3,8 \\
\hline $\begin{array}{l}\text { Dochody ze świadczeń } \\
\text { zubezpieczeń społecznych, } \\
\text { w tym: }\end{array}$ & 26,1 & 26,7 & 25,9 & 26,1 & 26,5 & 26,6 & 26,5 & 26,4 & 25,9 & 23,9 & 24,5 \\
\hline- z emerytur & 20,0 & 20,8 & 20,3 & 20,5 & 20,9 & 20,8 & 20,9 & 21,0 & 20,9 & 19,5 & 20,5 \\
\hline - z rent & 5,6 & 5,4 & 5,1 & 5,1 & 5,0 & 5,1 & 4,9 & 4,7 & 4,3 & 3,8 & 3,4 \\
\hline $\begin{array}{l}\text { Dochody z pozostałych } \\
\text { świadczeń społecznych }\end{array}$ & 3,6 & 3,4 & 3,5 & 3,3 & 3,4 & 3,6 & 3,4 & 3,3 & 6,3 & 7,4 & 6,7 \\
\hline $\begin{array}{l}- \text { w tym: ze świadczenia } \\
\text { wychowawczego }\end{array}$ & 3,4 & 3,0 & 3,1 & 3,0 & 3,1 & 3,2 & 3,2 & 3,1 & 3,0 & 4,4 & 4,0 \\
\hline Inne dochody & 4,7 & 4,7 & 4,8 & 4,4 & 4,6 & 4,4 & 5,0 & 4,5 & 4,1 & 4,0 & 3,8 \\
\hline
\end{tabular}

Rysunek 5. Struktura przeciętnych dochodów na jedną osobę w latach 2008-2018

Źródło: opracowanie własne na podstawie danych GUS, 2008-2018, Budżety gospodartw... 


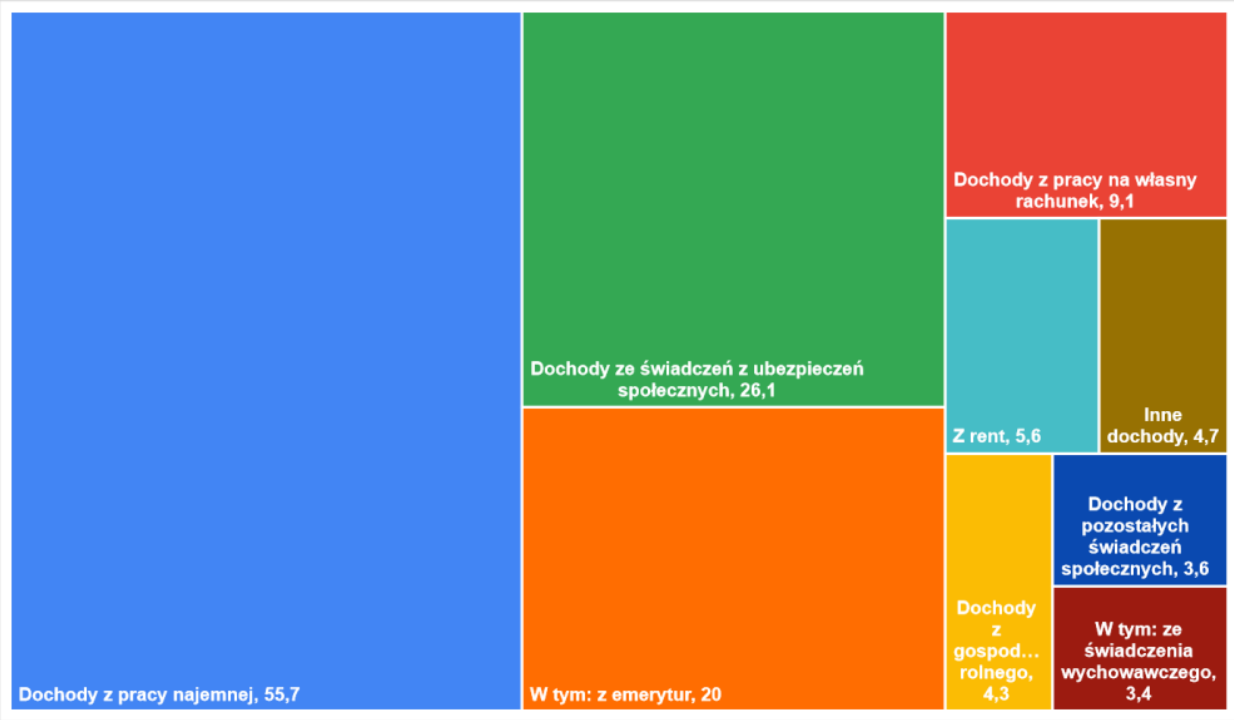

Rysunek 6. Struktura przeciętnych dochodów na jedną osobę w 2008 roku - ujęcie graficzne Źródło: opracowanie własne na podstawie danych GUS, 2008-2018, Budżety gospodartw...

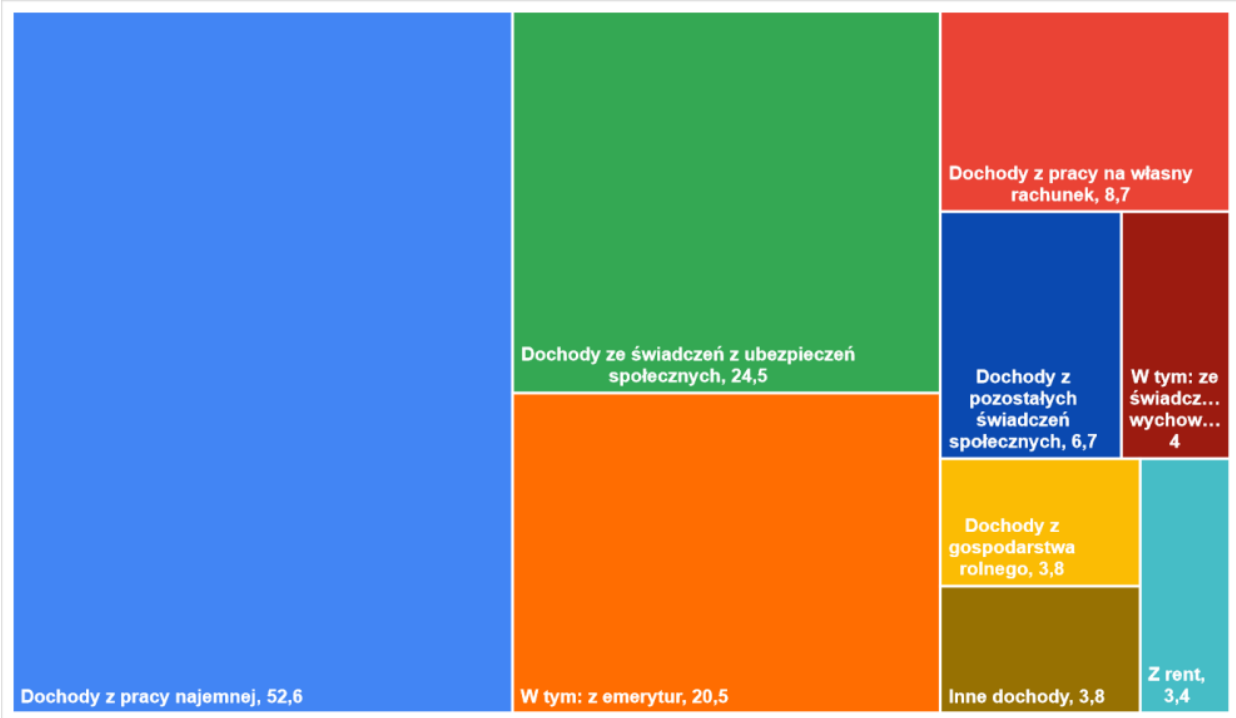

Rysunek 7. Struktura przeciętnych dochodów na jedną osobę w 2018 roku - ujęcie graficzne Źródło: opracowanie własne na podstawie danych GUS, 2008-2018, Budżety gospodartw... 
W ujęciu geograficznym, przeciętne dochody gospodarstw domowych w 2018 roku nie były równomierne w całym kraju. W zależności od województwa zamieszkania, średni dochód rozporządzalny plasował się na różnych poziomach. Zdecydowanie na tle kraju wyróżniało się województwo mazowieckie, w którym przeciętny poziom dochodów gospodarstw domowych wynosił $120 \%$ średniej dla kraju. Na drugim biegunie średniego poziomu dochodów sytuowało się województwo podkarpacie - przeciętny poziom dochodów gospodarstw domowych wynosił tam w 2018 roku zaledwie 79,6\% średniej krajowej. Mapa 1 przedstawia poziom średniego dochodu rozporządzalnego na 1 osobę $\mathrm{w}$ gospodarstwie domowym w odniesieniu do średniej krajowej (1693 zł).

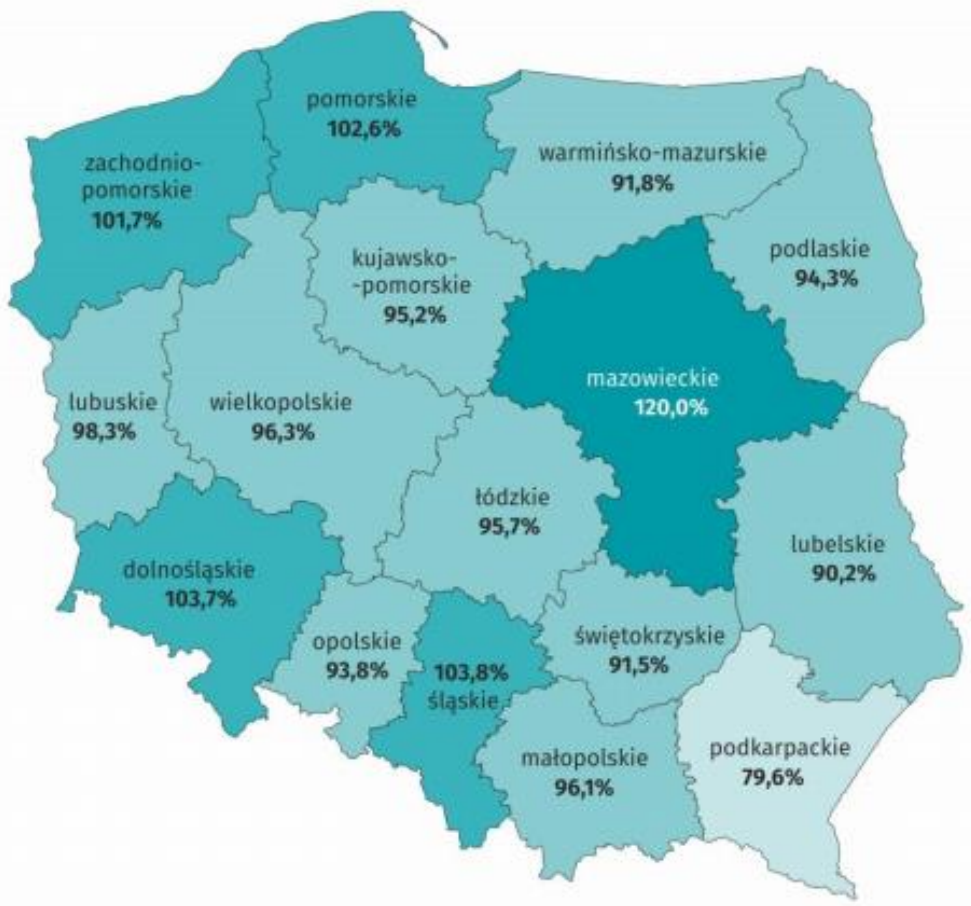

Mapa 1. Poziom średniego dochodu rozporządzalnego w odniesieniu do średniej krajowej w podziale na województwa w 2018 roku

Źródło: GUS, 2019, Budżety gospodarstw...

Wraz ze wzrostem dochodów w Polsce, rosły również przeciętne wydatki gospodarstw domowych. Najbardziej naturalną i intuicyjną przyczyną tego stanu rzeczy jest inflacja, która jest naturalnym procesem wzrostu cen. W okresie 2008- 
2018 w Polsce miała miejsce zarówno inflacja na poziomie kilku procent, ale również deflacja (w latach 2015-2016). W większości lat objętych badaniem panowała inflacja, co sprawiało, że ceny produktów i usług na rynku rosły.

\begin{tabular}{|l|c|c|c|c|c|c|c|c|c|c|c|}
\hline Wyszczególnienie & 2008 & 2009 & 2010 & 2011 & 2012 & 2013 & 2014 & 2015 & 2016 & 2017 & 2018 \\
\hline $\begin{array}{l}\text { Stopa inflacji w Polsce } \\
\text { [\%] }\end{array}$ & 4,20 & 3,50 & 2,60 & 4,30 & 3,70 & 0,90 & 0 & $-0,90$ & $-0,60$ & 2,00 & 1,60 \\
\hline
\end{tabular}

Rysunek 9. Inflacja w Polsce w latach 2008-2018

Źródło: opracowanie własne na podstawie danych GUS.

Oprócz inflacji, do przyczyn rosnących cen można zaliczyć skutki kryzysów gospodarczych (zarówno globalnego kryzysu z 2008 roku, jak i kryzysu fiskalnego z 2011 roku). Na trend wzrostowy przeciętnych wydatków gospodarstw domowych składają się też czynniki, takie jak:

- wzrost cen niektórych czynników produkcji,

- podwyżka podatków i opłat oraz wprowadzanie nowych danin,

- rosnąca urbanizacja (koszty życia w ośrodkach miejskich są wyższe niż w małych miastach i wsiach).

Największymi kategoriami wydatków w badanym okresie były wydatki na żywność i napoje bezalkoholowe oraz wydatki związane z użytkowaniem mieszkania (czynsze, opłaty za prąd, zużycie wody itp.) Do obszarów wydatków, w których zaszły największe zmiany, należą w badanym okresie:

- wydatki na restauracje i hotele - ta kategoria wzrosła ponad dwukrotnie,

- łączność - wydatki tej kategorii charakteryzowały się wyraźnym trendem spadkowym, dał,

- rekreacja i kultura - udział wydatków w tej kategorii systematycznie spa-

- żywność i napoje bezalkoholowe - widoczna była tendencja spadkowa udziału tego obszaru w strukturze wydatków.

Wzrost lub spadek udziału danej kategorii w strukturze przeciętnych wydatków, mógł być powodowany przez różnorakie czynniki:

- zmiana poziomu cen dóbr w danej kategorii,

- zmiana stylu życia,

- zmiana cen dóbr z innych kategorii. 


\begin{tabular}{|c|c|c|c|c|c|c|c|c|c|c|c|}
\hline $\begin{array}{l}\text { Kategoria } \\
\text { wydatków }\end{array}$ & 2008 & 2009 & 2010 & 2011 & 2012 & 2013 & 2014 & 2015 & 2016 & 2017 & 2018 \\
\hline $\begin{array}{l}\text { Żywność } \\
\text { i napoje } \\
\text { bezalkoholowe }\end{array}$ & 26,7 & 26,3 & 26,0 & 26,1 & 26,2 & 26,0 & 25,6 & 24,0 & 25,2 & 24,3 & 24,8 \\
\hline $\begin{array}{l}\text { Napoje } \\
\text { alkoholowe, } \\
\text { wyroby } \\
\text { tytoniowe } \\
\end{array}$ & 2,8 & 2,9 & 2,8 & 2,8 & 2,8 & 2,7 & 2,6 & 2,5 & 2,6 & 2,4 & 2,5 \\
\hline Odzież i obuwie & 5,8 & 5,5 & 5,5 & 5,3 & 5,1 & 5,3 & 5,6 & 5,4 & 5,8 & 5,3 & 4,9 \\
\hline $\begin{array}{l}\text { Użytkowanie } \\
\text { mieszkania, } \\
\text { koszty energii }\end{array}$ & 19,7 & 20,6 & 21,1 & 21,6 & 21,3 & 21,7 & 21,0 & 20,1 & 20,4 & 19,5 & 18,3 \\
\hline $\begin{array}{l}\text { Wyposażenie } \\
\text { mieszkania } \\
\text { i prowadzenie } \\
\text { gospodarstwa } \\
\text { domowego } \\
\end{array}$ & 5,8 & 5,6 & 5,4 & 5,0 & 5,0 & 4,9 & 5,1 & 5,0 & 5,3 & 5,2 & 5,7 \\
\hline Zdrowie & 5,0 & 5,2 & 5,0 & 5,2 & 5,2 & 5,3 & 5,2 & 5,3 & 5,6 & 5,5 & 5,0 \\
\hline Transport & 10,5 & 10,1 & 10,0 & 10,0 & 10,2 & 10,1 & 9,6 & 8,8 & 9,1 & 8,7 & 10,5 \\
\hline Łączność & 5,0 & 4,8 & 4,6 & 4,4 & 4,1 & 5,4 & 5,3 & 5,0 & 5,2 & 4,7 & 4,0 \\
\hline \begin{tabular}{|l|} 
Rekreacja \\
i kultura \\
\end{tabular} & 8,3 & 8,4 & 8,4 & 8,4 & 8,5 & 6,8 & 6,8 & 6,7 & 7,2 & 6,9 & 6,5 \\
\hline Edukacja & 1,3 & 1,3 & 1,3 & 1,3 & 1,2 & 1,2 & 1,1 & 1,0 & 1,0 & 1,0 & 1,0 \\
\hline $\begin{array}{l}\text { Restauracje } \\
\text { i hotele }\end{array}$ & 2,1 & 2,3 & 2,4 & 2,6 & 2,9 & 3,0 & 4,4 & 4,1 & 4,6 & 4,6 & 5,0 \\
\hline $\begin{array}{l}\text { Pozostałe } \\
\text { towary i usługi }\end{array}$ & 5,5 & 5,5 & 5,5 & 5,4 & 5,4 & 6,0 & 6,1 & 5,9 & 6,3 & 6,1 & 6,1 \\
\hline $\begin{array}{l}\text { Wydatki } \\
\text { pozostałe }\end{array}$ & 4,5 & 4,7 & 4,8 & 4,5 & 4,5 & 4,3 & 4,6 & 4,4 & 4,5 & 4,2 & 4,2 \\
\hline Kieszonkowe & 1,6 & 1,7 & 1,8 & 1,8 & 1,8 & 1,7 & 1,6 & 1,6 & 1,6 & 1,6 & 1,5 \\
\hline
\end{tabular}

Rysunek 10. Struktura wydatków polskich gospodarstw domowych na jedną osobę w latach 2008-2018

Źródło: opracowanie własne na podstawie danych GUS, 2008-2018, Budżety gospodartw... 


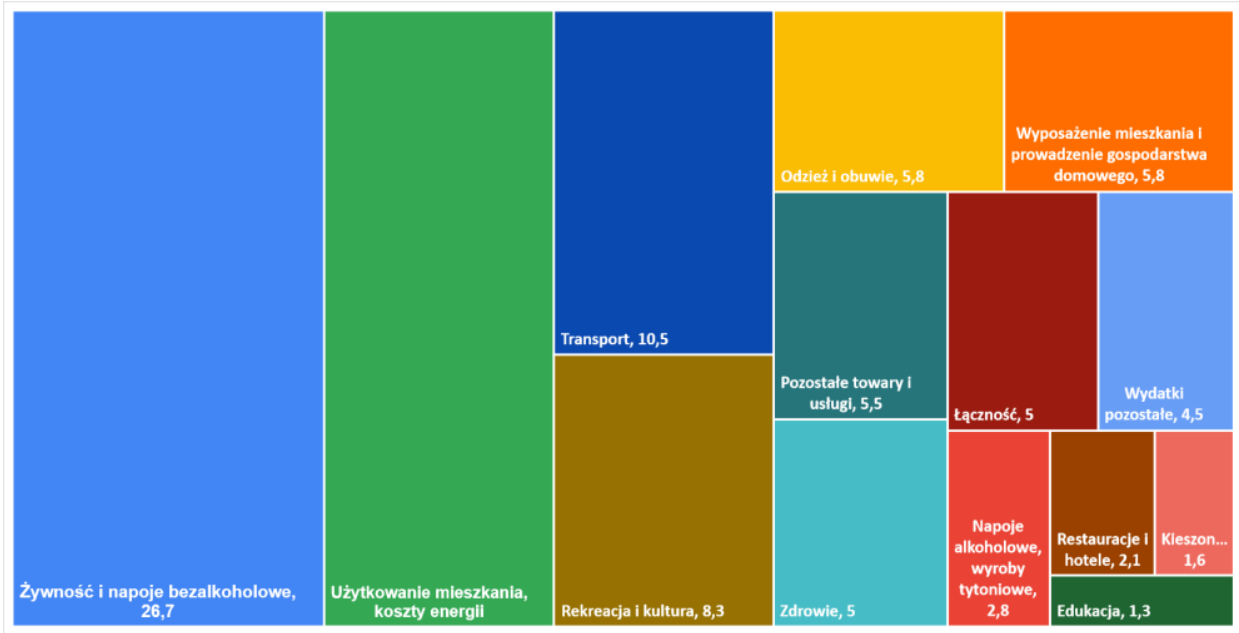

Rysunek 11. Struktura przeciętnych wydatków na jedną osobę 2008 roku - ujęcie graficzne

Źródło: opracowanie własne na podstawie danych GUS, 2008-2018, Budżety gospodartw...

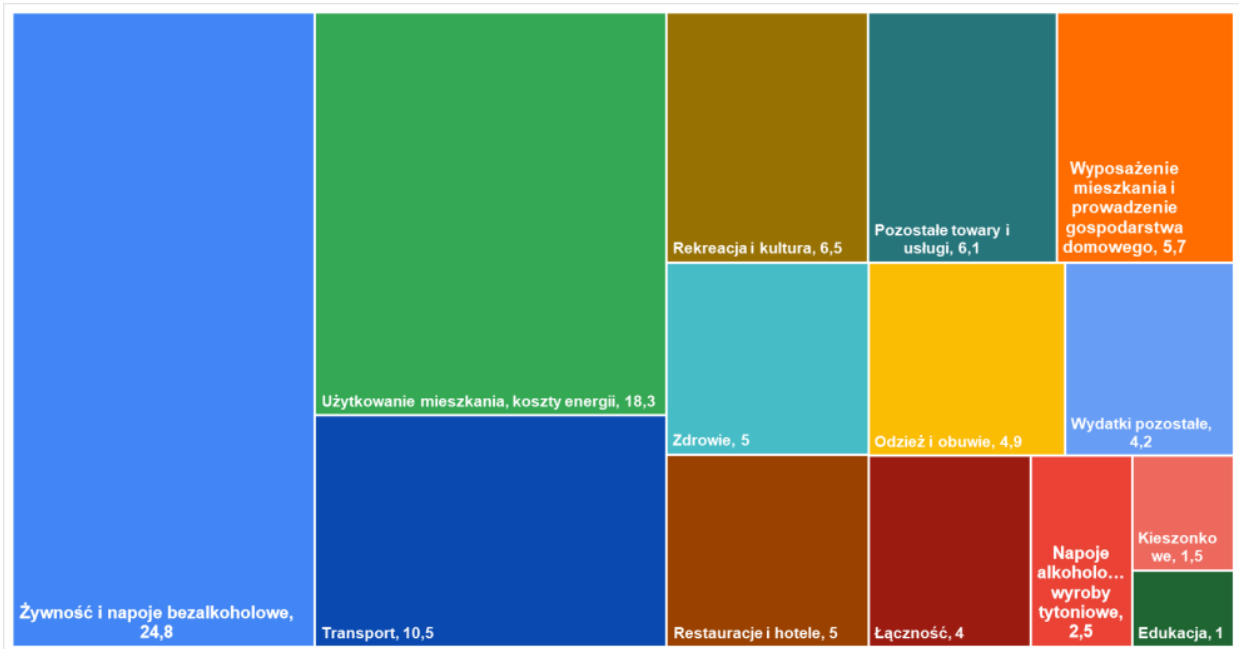

Rysunek 13. Struktura przeciętnych wydatków na jedną osobę w 2018 roku - ujęcie graficzne

Źródło: opracowanie własne na podstawie danych GUS, 2008-2018, Budżety gospodartw... 


\section{PODSUMOWANIE}

$\mathrm{Na}$ kształtowanie się struktury dochodów i wydatków gospodarstw domowych mają wpływ czynniki z różnych stref życia gospodarczego. Celem artykułu było zestawienie danych dotyczących struktury budżetów polskich gospodarstw domowych w latach 2008-2018 i wykazanie tendencji w nich zachodzących. Zagadnienie to jest bardzo złożone i zależy od wielu czynników. W niniejszym artykule budżet gospodarstwa domowego analizowany był w ujęciu statystycznym, celem ukazania ogólnokrajowych tendencji. Na kształtowanie się dochodów i wydatków przeciętnego polskiego gospodarstwa domowego ma wpływ szczególnie poziom rozwoju gospodarczego kraju, prowadzona polityka oraz poziomy wynagrodzeń (od strony dochodowej) oraz kryzysy gospodarcze, poziom inflacji i styl życia (od strony wydatkowej). Faktem są rosnące w ostatnich latach poziomy dochodów do dyspozycji oraz dochody rozporządzalne w polskich gospodarstwach domowych.

\section{BIBLIOGRAFIA}

Dominiak J., Konecka-Szydłowska B., 2014, Wpływ kryzysu na sytuację społeczno-gospodarczq gospodarstw domowych. Przykład Wielkopolski, „Biuletyn Rozwój Regionalny i Polityka Regionalna", $\mathrm{nr} 25$.

Główny Urząd Statystyczny w Poznaniu, 2015, Badanie budżetów gospodarstw domowych, Poznań. Gupta A.K., 2007, Industrial Automation and Robotics. Laxmi Publications (P) Ltd.

GUS, 2009, Budżety gospodarstw domowych w 2008 r., Warszawa.

GUS, 2010, Budzety gospodarstw domowych w 2009 r., Warszawa.

GUS, 2011, Budzety gospodarstw domowych w 2010 r., Warszawa.

GUS, 2012, Budzety gospodarstw domowych w $2011 \mathrm{r}$., Warszawa.

GUS, 2013, Budzety gospodarstw domowych $w 2012$ r., Warszawa.

GUS, 2014, Budzety gospodarstw domowych w 2013 r., Warszawa.

GUS, 2015, Budzety gospodarstw domowych w $2014 r$., Warszawa.

GUS, 2016, Budzety gospodarstw domowych w $2015 \mathrm{r}$., Warszawa.

GUS, 2017, Budzety gospodarstw domowych w $2016 r$., Warszawa.

GUS, 2018, Budzety gospodarstw domowych $w 2017$ r., Warszawa.

GUS, 2019, Budzety gospodarstw domowych w $2018 \mathrm{r}$., Warszawa.

GUS, 2019, Sytuacja demograficzna Polski do $2018 \mathrm{r}$. Tworzenie i rozpad rodzin, Warszawa.

GUS, www.stat.gov.pl, Pracujacy $i$ wynagrodzenia w gospodarce narodowej $w 2018$ r. - dane ostateczne [dostęp 30.06.2020].

GUS, www.stat.gov.pl, Przeciętne miesięczne wynagrodzenie $w$ gospodarce narodowej $w$ latach 1950-2018 [dostęp 30.06.2020].

GUS, www.stat.gov.pl, Roczne wskaźniki cen towarów i usług konsumpcyjnych od 1950 roku [dostęp 30.06.2020].

GUS, www.stat.gov.pl, Stopa bezrobocia rejestrowanego w latach 1990-2020 [dostęp 30.06.2020].

Holzer J., 2003, Demografia, PWE, Warszawa.

Koźmiński A.K., Piotrowski W., 2002, Zarządzanie. Teoria i praktyka, Wydawnictwo Naukowe PWN, Warszawa.

Leksykon naukowo-techniczny, 1984, WNT, Warszawa.

Marek S., Białasiewicz M. (red.), 2008, Podstawy nauki o organizacji, PWE, Warszawa. 
Ministerstwo Rodziny i Polityki Społecznej, https://www.gov.pl/web/rodzina/rodzina-500-plus [dostęp 15.06.2020].

Okólski M., 2020, Encyklopedia PWN, https://encyklopedia.pwn.pl/haslo/demografia;3891703.html\#enc-bibliografia [dostęp 26.06.2020].

Pekasiewicz D., Szczukocka A., 2017, Analiza rozwoju nowych technologii w gospodarstwach domowych w Polsce, „Nierówności Społeczne a Wzrost Gospodarczy”, nr 52(4/2017).

Pizło W., Mazurkiewicz-Pizło A., 2017, Styl życia-jako egzemplifikacja zmian zachowań, „Zeszyty Naukowe SGGW w Warszawie. Polityki Europejskie, Finanse i Marketing”, nr 17(66).

Weiner J., 1999, „Życie i ewolucja biosfery”, Wydawnictwo Naukowe PWN, Warszawa.

Węcławowicz G., 2003, Geografia społeczna miast, Wydawnictwo Naukowe PWN, Warszawa.

Węgleński J., 2002, Encyklopedia socjologii, Oficyna Naukowa, Warszawa.

Zalega T., 2012, Zmiany $w$ wyposażeniu gospodarstw domowych $w$ dobra trwatego użytku w okresie kryzysu. Ekonomika i organizacja gospodarki żywnościowej, „Zeszyty Naukowe SGGW”, nr 98 .

\section{CHANGES IN THE BUDGET STRUCTURE OF POLISH HOUSEHOLDS IN THE YEARS 2008-2018}

In recent years, the economic situation in Poland has undergone dynamic changes. These changes had an impact on the standard of living of Poles, by affecting their financial situation. The article presents and analyzes the characteristics of changes in the structure of polish household budgets in 2008-2018. Issues such as income and expenditure, expenditure structure, tendency and dynamics of changes, including demographic and economic factors, has been discused in this article. In addition to analyzing the data on the structure of household budgets, the causes responsible for such and not other directions of changes has been also identified.

Keywords: budget structure, households, changes, economic environment, political environment, social environment, technological environment. 